\title{
KARAKTERISTIK DAN POLA PENGGUNAAN OBAT ANALGESIK NSAID PADA PASIEN PASCA OPERASI DI RSUD ABDUL WAHAB SJAHRANIE SAMARINDA
}

\author{
Kurnia Rizki Ramadani ${ }^{1, *}$, Dewi Rahmawati ${ }^{2}$, Arsyik Ibrahim $^{2}$ \\ ${ }^{1}$ RSUD Abdul Wahab Sjahranie Samarinda \\ ${ }^{2}$ Fakultas Farmasi Universitas Mulawarman, Samarinda, Kalimantan Timur \\ *Email: rizkiramadani17@gmail.com
}

\begin{abstract}
NSAID analgesic is a peripheral analgesic drug that can inhibit prostaglandin synthesis through the inhibition of the enzyme cyclooxygenase. The purpose of this study was to know the characteristic and examined the use of NSAID analgesic drugs as antipain medications in patients postoperatively. Method used in this study is a nonexperimental descriptive. This study involved 90 patients who subsequently characterized by gender, age, last education level and type of surgery. Then classified NSAID analgesic drug use. The results obtained in 54,44\% were male and 45,56\% were female. Age youth as much as 10\%, 50\% adults and 40\% elderly. Major surgery obtained in 56,66\% and minor surgery 43,33\%. Patterns of drug use obtained 38,88\% use derivate pirazoline, $14,44 \%$ derivate pyrrolizine carboxylic acid, 5,55\% derivate fenamates, 4,44\% derivate propionic acid, 1,11\% derivate para-aminophenols, $0 \%$ derivate acetic acids, and 35,55\% the use of drug combinations. The dose of each therapy overall appropriate. A single oral route of administration 11,11\%; parenteral single 54,4\%; and a combination of both $34,44 \%$.
\end{abstract}

Keywords : Surgery, pain, NSAID analgesic

\begin{abstract}
ABSTRAK
Analgesik NSAID merupakan obat analgesik perifer yang dapat menghambat sintesis prostaglandin melalui penghambatan enzim siklooksigenase. Tujuan penelitian ini adalah untuk mengetahui karakteristik dan mengkaji penggunaan obat analgesik NSAID sebagai obat anti nyeri pada pasien pasca operasi. Metode penelitian yang digunakan berupa metode non eksperimental secara deskriptif. Penelitian ini melibatkan 90 orang pasien yang kemudian dikarakterisasikan berdasarkan jenis kelamin, usia, tingkat pendidikan terakhir dan jenis operasi. Kemudian dikelompokkan penggunaan obat analgesik NSAID. Hasil yang diperoleh sebanyak $54,44 \%$ berjenis kelamin laki-laki dan $45,56 \%$ berjenis kelamin perempuan. Usia remaja sebanyak 10\%, dewasa $50 \%$ dan lansia $40 \%$. Jenis operasi major sebanyak 56,66\% dan operasi minor $43,33 \%$. Dari pola penggunaan obat yang diperoleh $38,88 \%$ digunakan turunan pirazolin, $14,44 \%$ turunan asam karboksilat pirolizin, 5,55\% turunan fenamat, 4,44\% turunan asam propionat, 1,11\% turunan paraaminofenol, $0 \%$ turunan asam asetat dan 35,55\% penggunaan obat kombinasi. Dosis yang digunakan dari setiap terapi secara keseluruhan telah sesuai. Rute pemberian tunggal oral $11,11 \%$; tunggal parenteral 54,4\%; dan kombinasi keduanya 34,44\%.
\end{abstract}


Kata Kunci : Operasi, nyeri, analgesik NSAID

\section{PENDAHULUAN}

Operasi merupakan tindak pengobatan yang umumnya dilakukan dengan memasukkan suatu alat kedalam tubuh dengan cara menampilkan bagian tubuh yang akan ditangani (Sjamsuhidajat R, 2010). Proses perawatan pada pasien yang telah melakukan operasi dikenal sebagai pasca operasi. Dalam tindakan perawatannya akan menimbulkan berbagai keluhan dan gejala, dimana yang paling dominan adalah rasa nyeri. Angka kejadian operasi dikalangan masyarakat setiap tahunnya semakin meningkat, baik operasi besar maupun operasi kecil. Di pertengahan tahun 2014, angka kejadian operasi di RSUD Abdul Wahab Sjahranie mencapai sekitar 5.558 kejadian operasi. Sedangkan, di pertengahan tahun 2015, mencapai sekitar 6.000 kejadian operasi. Sekitar $80 \%$ dari pasien mengalami nyeri akut setelah operasi (Misiolek et al., 2014). Dilihat dari angka kejadian yang ada, penatalaksanaan nyeri pasca operasi perlu mendapatkan perhatian khusus sehingga pengelolaan nyeri pasca operasi yang optimal tidak hanya mengurangi penderitaan pasien, melainkan juga meningkatkan kualitas hidupnya. Penelitian ini bertujuan untuk mengetahui karakteristik pasien pasca operasi yang menggunakan obat analgesik NSAID dan mengkaji penggunaan obat analgesik NSAID sebagai obat anti nyeri pada pasien yang telah mengalami operasi. Manfaat dalam penelitian ini adalah dapat memberikan informasi mengenai karakteristik pasien pasca operasi dan pola penggunaan obat pasien pasca operasi yang menggunakan obat analgesik NSAID sebagai obat anti nyeri.

Nyeri merupakan pengalaman sensoris dan emosional yang tidak menyenangkan yang disertai oleh kerusakan jaringan secara potensial dan aktual. Nyeri sering diasosiasikan dengan kerusakan jaringan, akan tetapi nyeri dapat saja timbul tanpa adanya kerusakan, dimana nyeri timbul tanpa berhubungan dengan sumber yang dapat diidentifikasikan. Berdasarkan mekanismenya, nyeri melibatkan persepsi dan respon terhadap nyeri tersebut. Persepsi merupakan proses yang subjektif, dimana tidak hanya berkaitan dengan proses fisiologis atau anatomi saja, tetapi juga meliputi kognisi dan memori (Ardinata, 2007).

Analgesik terbagi atas dua golongan, yaitu analgesik opioid dan analgesik nonopioid/ NSAID (Non Steroid Anti Inflammatory Drug). Golongan opioid dapat menghambat nyeri lebih kuat daripada NSAID dengan mengaktifkan reseptor $\mu$ yang tersebar diberbagai tempat di otak, sehingga sinyal nosiseptif dihambat secara sentral (Hargreavers K, 2006)). Sedangkan, NSAID bekerja di perifer yang secara spesifik menghambat enzim siklooksigenase (COX), yang merupakan enzim penting dalam jalur asam arakidonat untuk menghasilkan prostaglandin. Ketika ada stimulus, membran fosfolipid akan menghasilkan fosfolipase- $\mathrm{A}_{2}$ yang kemudian menstimulasi asam arakidonat untuk menghasilkan enzim COX dan membantu endoperoksida untuk menghasilkan prostaglandin, prostasiklin, dan tromboksan. COX terbagi atas dua bagian, yaitu COX-1 dan COX-2. COX-1 bersifat konstitutif, yaitu keberadaannya selalu tetap dan tidak dipengaruhi stimulus. COX-1 berperan normal dalam tubuh untuk menghasilkan prostaglandin yang dibutuhkan oleh tubuh. Sedangkan, COX-2 bersifat indusibel, yaitu keberadaannya dipengaruhi oleh adanya stimulus (McClay, 2010). Kelompok obat NSAID terbagi atas tiga kelas, yaitu analgesik sederhana, NSAID non selektif, dan inhibitor selektif COX-2. Analgesik sederhana seperti parasetamol; NSAID non selektif seperti natrium diklofenak, asam mefenamat, natrium naproksen, meloksikam, dan ketorolak; dan inhibitor selektif COX-2 seperti celecoxib, etoricoxib, dan parecoxib. 
Untuk lebih meningkatkan kewaspadaan dan ketelitian dalam memberi dan menggunakan obat sehingga perlu dilakukan pengkajian lebih mendalam karena itulah, penulis berkeinginan untuk memilih topik ini sebagai judul penelitian.

\section{METODE PENELITIAN}

Penelitian ini merupakan penelitian non eksperimental secara deskriptif. Populasi dalam penelitian ini adalah seluruh pasien pasca operasi yang ada didalam ruang rawat inap Cempaka di RSUD Abdul Wahab Sjahranie Samarinda. Teknik penarikan sampel yang dilakukan berdasarkan karakteristik atau kriteria tertentu yang telah ditetapkan oleh peneliti.

\section{Peralatan}

Peralatan yang digunakan adalah sebagai berikut:
1. Alat tulis
: Sebagai alat untuk menulis data yang diperoleh dari observasi dan rekam medik
2. Buku catatan : Sebagai media penulisan data-data yang bersumber dari hasil observasi dan rekam medik
3. Laptop : Sebagai alat untuk mengolah data dan menganalisis data
4. Rekam medik : Sebagai sumber data sekunder pasien yang akan diteliti

\section{Prosedur}

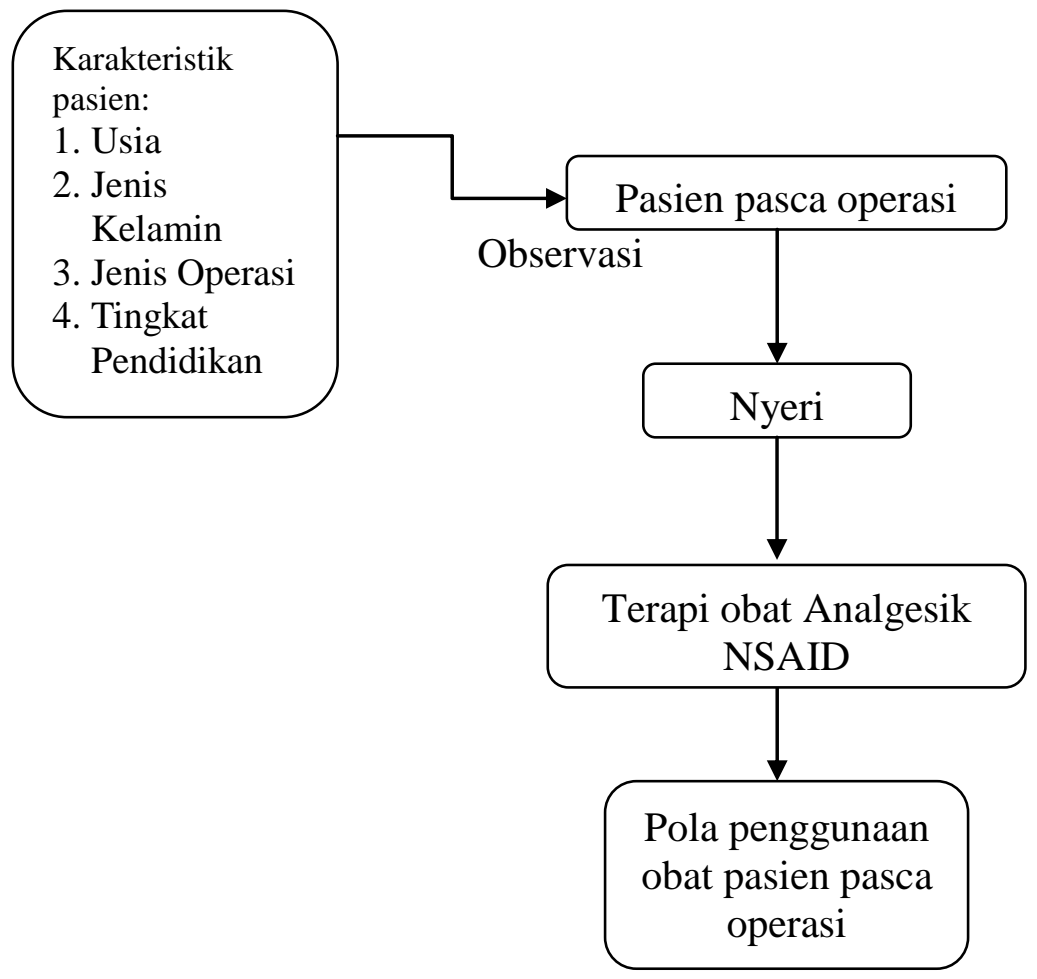

Gambar 1. Prosedur Pengumpulan Data 


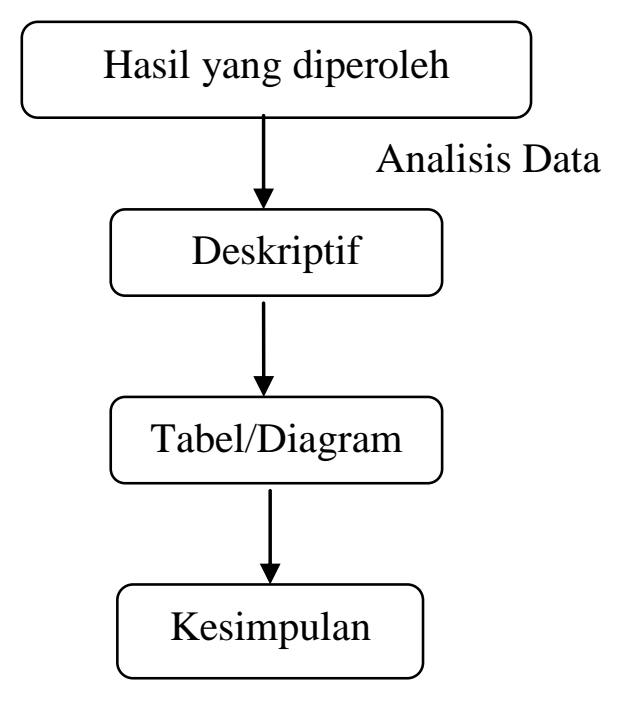

Gambar 2. Prosedur Analisis Data

\section{HASIL DAN PEMBAHASAN}

Pasien pasca operasi yang menjadi sampel dalam penelitian ini sebanyak 90 orang pasien dengan berbagai diagnosa dan tindakan operasi. Kemudian pasien dikarakterisasi berdasarkan jenis kelamin, usia, jenis operasi dan tingkat pendidikan. Berdasarkan Tabel 1. menunjukkan bahwa sebanyak 54,44\% pasien berjenis kelamin laki-laki, sedangkan pasien yang berjenis kelamin perempuan sebanyak 45,56\%. Dimana umumnya, pasien laki-laki lebih banyak didiagnosa kelainan pada sistem urinaria dan alat kelamin seperti Benign Prostatic Hyperplasia/BPH dan Batu Saluran Kemih/BSK. Hal ini sesuai dengan penelitian Mahendrakrisna et al. (2016) yang menyatakan bahwa di Indonesia pembesaran prostat jinak sering ditemukan pada laki-laki dewasa, yang mana insiden penyakit ini dimulai pada usia 50 tahun dan meningkat seiring pertambahan usia. Selain itu, dalam penelitian Lina (2008), menyatakan bahwa batu saluran kemih lebih banyak diderita oleh laki-laki dengan angka kejadian 3 kali lebih daripada perempuan. Hal ini karena kadar kalsium air kemih sebagai baha utama pembentuk batu lebih rendah pada perempuan daripada laki-laki, kadar sitrat air kemih sebagai bahan penghambat terjadinya batu pada perempuan lebih tinggi daripada laki-laki. Selain itu, hormon estrogen pada perempuan mampu mencegah agregasi garam kalsium, sedangkan hormon testosterone yang tinggi pada laki-laki menyebabkan peningkatan oksalat endogen oleh hati yang selanjutnya memudahkan terjadinya kristalisasi.

Tabel 1. Distribusi pasien pasca operasi berdasarkan jenis kelamin

\begin{tabular}{ccc}
\hline Jenis Kelamin & Jumlah & Persentase \\
\hline Laki-laki & 49 & $54,44 \%$ \\
Perempuan & 41 & $45,56 \%$ \\
\hline Total & 90 & $100 \%$ \\
\hline
\end{tabular}




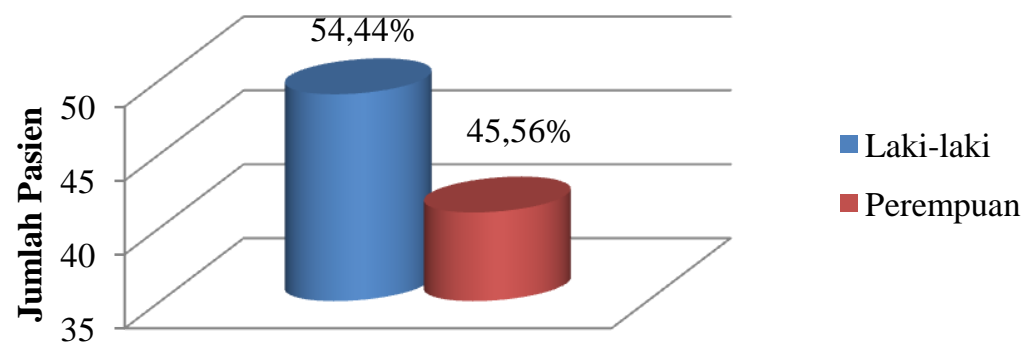

Gambar 3. Distribusi pasien pasca operasi berdasarkan jenis kelamin

Menurut Departemen Kesehatan/Depkes (2009), usia remaja akhir berada pada rentang usia 17-25 tahun, usia dewasa awal berada pada rentang usia 26-35 tahun, usia dewasa akhir berada pada rentang usia 36-45 tahun, dan usia lansia berada pada rentang 46 tahun keatas.

Tabel 2. Distribusi pasien pasca operasi berdasarkan usia

\begin{tabular}{ccc}
\hline Usia & Jumlah & Persentase \\
\hline $17-25$ (Remaja) & 9 & $10 \%$ \\
$26-45$ (Dewasa) & 45 & $50 \%$ \\
$46-65$ (Lansia) & 36 & $40 \%$ \\
\hline
\end{tabular}

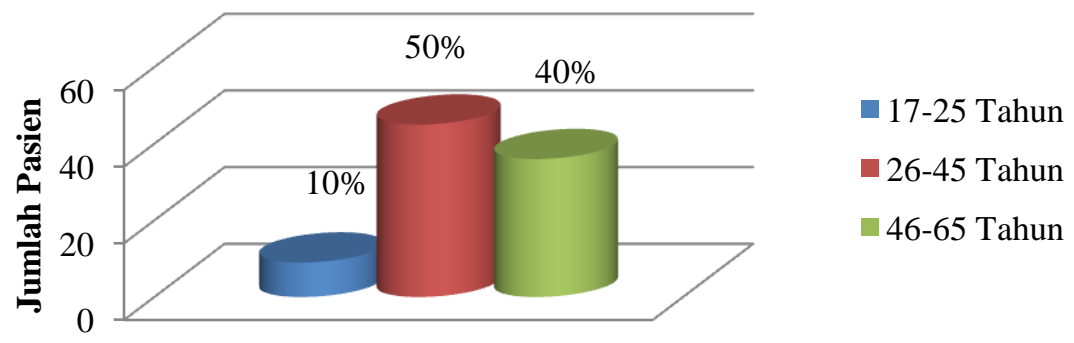

Gambar 4. Distribusi pasien pasca operasi berdasarkan usia

Berdasarkan Tabel 2. pasien dengan usia remaja sebanyak 10\%, usia dewasa sebanyak 50\%, dan usia lansia sebanyak 40\%. Dimana umumnya, pasien usia dewasa lebih banyak didiagnosa kelainan pada sistem urinaria seperti Batu Saluran Kemih/BSK. Hal ini telah sesuai menurut teori, dimana batu saluran kemih umumnya didapatkan pada dekade ketiga sampai kelima (Purnomo, 2003). Dalam penelitian Prawira R. A. (2015), juga mengungkapkan bahwa frekuensi kasus batu kandung kemih akan mengalami peningkatan setelah umur 50 tahun ke atas, dimana ukuran batu akan lebih besar dan tingkat komorbiditas yang lebih sering. Selain itu, pasien laki-laki dengan usia dewasa juga banyak didiagnosa kerusakan pada sistem muskuloskeletal berupa cedera/fraktur, baik akibat kecelakaan lalu lintas maupun kecelakaan kerja. Hal ini serupa dengan penelitian Riyadina et al. (2009), yang memaparkan bahwa proporsi cedera paling banyak dialami pada laki-laki $(31,9 \%)$ dengan usia dewasa $(38,8 \%)$. 
Berdasarkan Tabel 4. pasien yang tidak bersekolah dan yang melanjutkan studi profesi sebanyak 1,1\%. Pasien dengan tingkat pendidikan sekolah dasar sebanyak 27,78\%. Pasien dengan tingkat pendidikan sekolah menengah pertama sebanyak $17,77 \%$ dan sekolah menengah atas sebanyak 43,3\%. Sedangkan, pasien dengan tingkat pendidikan sarjana sebanyak 8,89\%. Pasien dengan pendidikan terakhir SMA, banyak didiagnosa kelainan pada sistem urinaria dan alat kelamin seperti Benign Prostatic Hyperplasia/BPH dan Batu Saluran Kemih/BSK, serta cedera/fraktur. Namun, belum ada penelitian yang mengungkapkan adanya hubungan tingkat pendidikan terakhir dengan angka kejadian penyakit tersebut.

Tabel 3. Distribusi pasien pasca operasi berdasarkan tingkat pendidikan terakhir

\begin{tabular}{ccc}
\hline Tingkat Pendidikan & Jumlah & Persentase \\
\hline Tidak Sekolah & 1 & $1,1 \%$ \\
SD & 25 & $27,78 \%$ \\
SMP & 16 & $17,77 \%$ \\
SMA & 39 & $43,3 \%$ \\
S1 & 8 & $8,89 \%$ \\
Apoteker & 1 & $1,1 \%$ \\
\hline
\end{tabular}

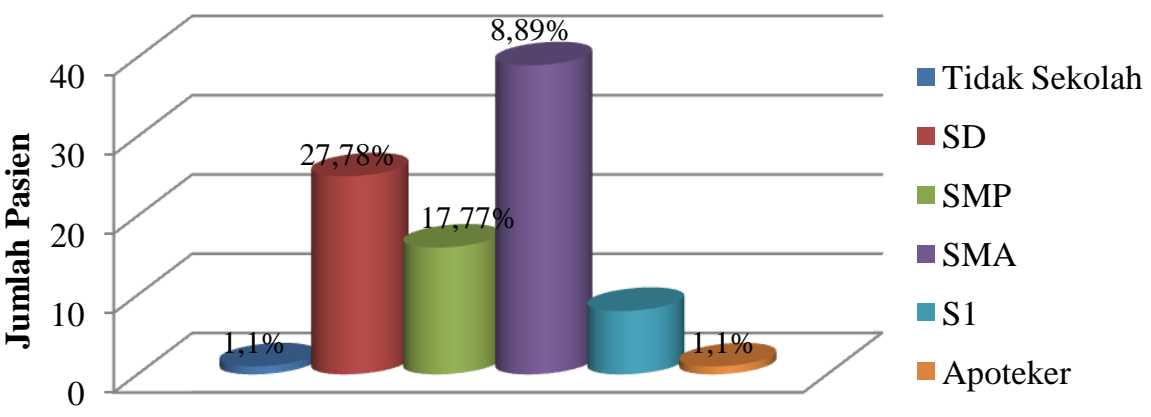

Gambar 5. Distribusi pasien pasca operasi berdasarkan tingkat pendidikan terakhir

Semua tindak pengobatan yang menggunakan cara invasif dikenal dengan nama operasi atau pembedahan. Selain bertujuan untuk menyelamatkan nyawa pasien, operasi juga bertujuan untuk mengangkat atau memperbaiki bagian tubuh, fungsi tubuh, dan meningkatkan kesehatan pasien. Klasifikasi operasi berdasarkan tingkat risiko atau keseriusannya terbagi menjadi dua bagian, yaitu operasi major dan operasi minor. Dimana dijelaskan bahwa operasi major melibatkan rekonstruksi atau perubahan yang luas di bagian tubuh, khususnya organ tubuh utama, menimbulkan risiko besar karena memiliki tingkat risiko yang tinggi terhadap kelangsungan hidup pasien, memerlukan rawat inap yang biasanya lama untuk masa penyembuhannya, situasi yang mengancam jiwa dan komplikasi pasca operasi yang potensial. Operasi major bisa bersifat elektif atau terencana, mendesak atau darurat. Sebaliknya, operasi minor merupakan operasi yang memiliki tingkat risiko rendah dan biasanya memerlukan waktu pengerjaan yang singkat (Basavanthappa, 2003). Selain itu, operasi major berarti operasi yang dilakukan menggunakan anestesi umum, sedasi dalam, atau pemblokiran konduksi utama. Sedangkan, operasi minor berarti operasi yang dilakukan menggunakan anestesi lokal, baik 
menggunakan sedasi oral pada pra operasi atau tidak (Committee MMS, 2011). Berikut adalah pengklasifikasian jenis operasi major dan minor berdasarkan diagnosa dan tindakan operasinya terhadap pasien diruang rawat inap Cempaka di RSUD Abdul Wahab Sjahranie Samarinda.

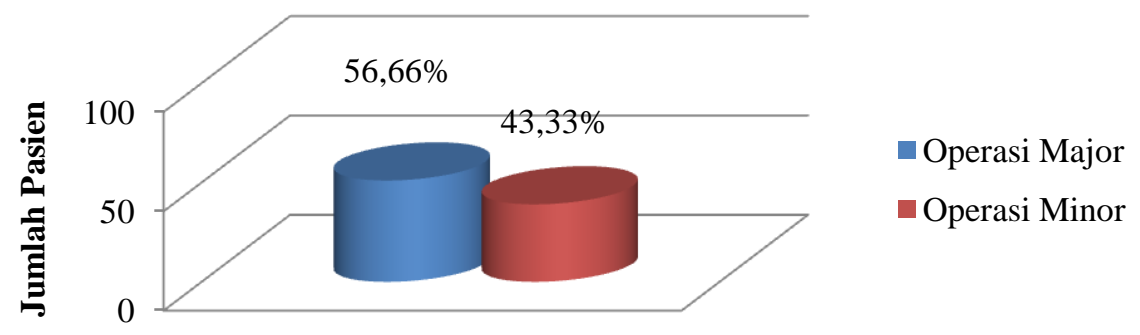

Gambar 6. Distribusi pasien pasca operasi berdasarkan jenis operasi

Gambar 6. menunjukkan bahwa pasien yang melakukan operasi major sebanyak $56,66 \%$ dan yang menjalani operasi minor sebanyak 43,33\%. Dari tindakan operasi yang ada, yang paling banyak dilakukan adalah tindakan operasi debrideman dan ORIF (Open Reduction and Internal Fixation) sebanyak 10 pasien. Kemudian tindakan operasi eksisi sebanyak 8 pasien, tindakan opersai removal implant sebanyak 7 pasien, tindakan operasi URS (Ureterorenescopy) dan TURP (Transurethral Resection of the Prostate) sebanyak 5 pasien, tindakan operasi odontektomi sebanyak 4 pasien, tindakan operasi istmolobektomi, tiroidektomi total, laparotomi apendektomi, aff implan, aff $\mathrm{Dj}$ Stent, sistoskopi, uretroplasti, hemoroidopeksi, dan kolesistektomi sebanyak 2 pasien. Sedangkan, tindakan operasi lainnya sebanyak 1 pasien.

Terapi pengobatan NSAID yang diberikan kepada pasien pasca operasi diruang rawat inap Cempaka di RSUD Abdul Wahab Sjahranie Samarinda tampak seperti grafik berikut.

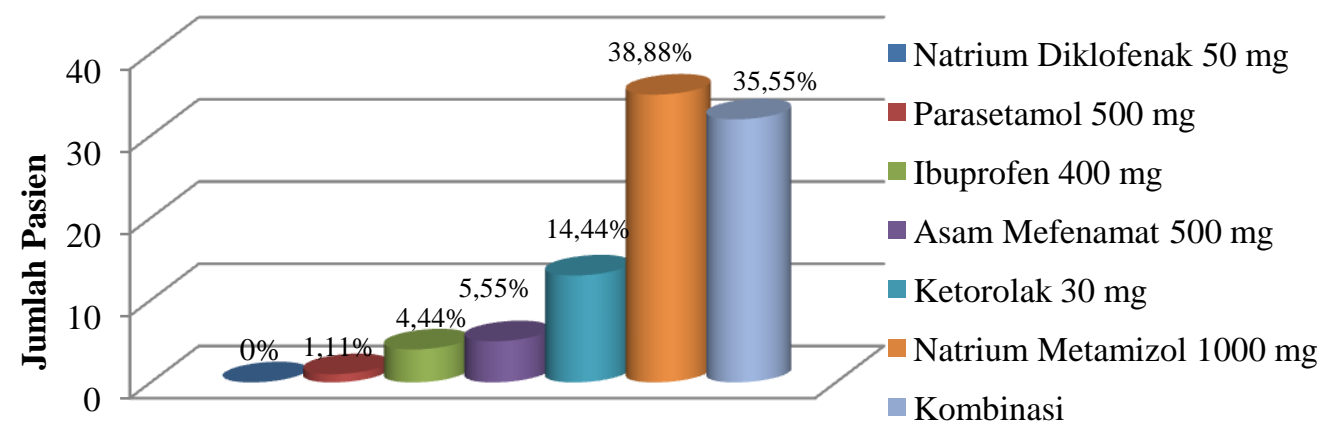

Gambar 7. Distribusi penggunaan obat analgesik NSAID pada pasien pasca operasi

Gambar 7. menunjukkan bahwa penggunaan obat natrium metamizol $1000 \mathrm{mg}$ paling banyak diberikan kepada pasien, bahkan hampir semua tindakan operasi menggunakan terapi ini sebagai pengobatan hari pertama pasca operasi, baik penggunaan tunggal maupun kombinasi. Kemudian obat yang lebih banyak diberikan sebagai pengobatan hari pertama 
pasca operasi adalah ketorolak $30 \mathrm{mg}$. Asam mefenamat $500 \mathrm{mg}$ dan ibuprofen $400 \mathrm{mg}$ juga banyak diberikan kepada pasien pasca operasi dan digunakan sebagai terapi hari pertama setelah operasi. Sedangkan, parasetamol $500 \mathrm{mg}$ jarang digunakan sebagai terapi hari pertama. Parasetamol $500 \mathrm{mg}$ dan natrium diklofenak $50 \mathrm{mg}$ lebih banyak digunakan sebagai terapi tambahan setelah beberapa hari pasca operasi (kombinasi). Kombinasi yang dimaksud dalam grafik diatas merupakan tahapan penggunaan obat yang berbeda selama terapi penyembuhan, yang mana setiap pasien tidak hanya menggunakan satu jenis obat saja tetapi lebih, bukan menggunakan dua atau lebih jenis obat secara bersamaan tetapi, secara bertahap, seperti terapi hari pertama menggunakan ketorolak $30 \mathrm{mg}$, terapi hari kedua menggunakan ibuprofen $400 \mathrm{mg}$. Begitu pula pada pasien yang telah melakukan operasi major dan membutuhkan perawatan lebih lama dirumah sakit.

Metamizol merupakan obat yang bekerja sebagai analgesik dan antipiretik dari kelompok turunan pirazolin. Obat ini diberikan sebagai prodrug secara oral, rektal, intramuskular, atau intravena. Dalam penelitian ini, obat metamizol digunakan dalam bentuk sediaan ampul dan diberikan secara intravena. Mula kerja obat setelah pemberian secara intravena adalah 30 menit dengan durasi obat didalam tubuh selama 4 jam. Absorpsi obat setelah pemberian oral adalah cepat dan hampir sempurna, dengan bioavailabilitas 85\% dan waktu konsentrasi maksimum dalam plasma sekitar 1,2-2 jam. Dalam kasus toksisitas ataupun overdosis, metamizol dapat dieliminasi dari darah dengan menggunakan hemodialisis. Dalam mekanismenya, metamizol akan dihidrolisis menjadi metabolit aktifnya, yaitu 4-metil-amino-antipirin (4-MAA) dan aminoantipirin (AA). Metabolit tersebut akan diekskresikan melalui ginjal dengan waktu paro 2,5-3,5 jam (Misiolek et al., 2014). Secara farmakologis, metamizol yang telah digunakan berpuluh-puluh tahun sebelumnya dianggap sebagai non selektif COX-1 dan inhibitor COX-2. Kemungkinan besar, efek analgesik dari metamizol dicapai melalui kerja dari COX-3 dan berdampak kedalam sistem opioidergik dan sistem kanabinoid. Penafsiran kembali dari mekanisme yang melibatkan kerja dari pengobatan ini didorong oleh penemuan isoform siklooksigenase. Menurut referensi yang ada, metamizol bertindak sebagai pereda nyeri dengan menghalangi COX-3 (variasi lanjutan dari COX-1), yang terjadi di sistem saraf pusat. Penghambatan COX-3 menyebabkan penurunan sintesis prostaglandin $\mathrm{E}_{2}\left(\mathrm{PGE}_{2}\right) \mathrm{di}$ sistem saraf pusat, sehingga sensitivitas nosiseptor ke mediator nyeri berkurang dan efek analgesik tercapai. Dalam sistem kanabinoid, amida arakidonoil (hasil dari metabolit aktif metamizol dengan asam lemak amida hidrolase) bersifat agonistik terhadap reseptor kanabinoid tipe 1 (CB1), yang juga merupakan reseptor antinosiseptif. Dalam sistem opioidergik endogen, injeksi metamizol dapat menginduksi antinosiseptif pada tempat analgesik opioidergik, yaitu PAG/Periaqueductal grey. Metamizol tidak dapat diklasifikasikan sebagai NSAID, sebab obat ini memiliki efek anti inflamasi yang lemah dibandingkan dengan obat NSAID (Jasiecka et al., 2014).

Secara umum, diketahui kerja obat NSAID adalah dengan menghambat enzim siklooksigenase (COX-1 atau COX-2) secara tidak selektif dengan cara berkompetisi dengan asam arakidonat untuk mengikat sisi aktif COX. Dalam penelitian ini obat NSAID yang digunakan berupa ketorolak $30 \mathrm{mg}$ dan $10 \mathrm{mg}$, asam mefenamat $500 \mathrm{mg}$, ibuprofen $400 \mathrm{mg}$, parasetamol $500 \mathrm{mg}$, dan natrium diklofenak $50 \mathrm{mg}$. Efek analgesik dari NSAID dapat digambarkan melalui angka yang dibutuhkan untuk pengobatan (Number needed to treat/NNT), yang merupakan angka yang dibutuhkan pasien, yang mana untuk menerima satu obat aktif untuk mencapai setidaknya $50 \%$ pereda nyeri dibandingkan dengan placebo setelah 4-6 jam pengobatan. Ketorolak $30 \mathrm{mg}$ memiliki NNT sebesar 3,4 dan ketorolak 10 mg memiliki NNT sebesar 2,6; asam mefenamat $500 \mathrm{mg}$ memiliki NNT sebesar 4,0; ibuprofen $400 \mathrm{mg}$ memiliki NNT sebesar 2,4; parasetamol $500 \mathrm{mg}$ memiliki NNT sebesar 3,5; dan natrium diklofenak $50 \mathrm{mg}$ memiliki NNT sebesar 2,3. Meskipun NNT pada 
ketorolak $30 \mathrm{mg}$ lebih rendah daripada asam mefenamat dan parasetamol, tetapi mula kerja ketorolak yang diberikan secara intravena lebih cepat. Sedangkan, obat ketorolak $10 \mathrm{mg}$ hanya digunakan pasien untuk terapi paliatif. Dari nilai NNT yang diperoleh, dapat dikatakan bahwa hasil yang diperoleh dengan literatur yang ada telah sesuai, dimana obat dengan nilai NNT yang lebih besar dapat menghilangkan nyeri lebih baik daripada nilai NNT yang lebih kecil. Meskipun ibuprofen memiliki nilai NNT yang lebih rendah dibanding parasetamol, namun dapat dilihat dari penggunaan dosis yang diberikan. Dalam tabel Oxford League yang menampilkan nilai NNT untuk analgesik pada nyeri akut menunjukkan bahwa ibuprofen $400 \mathrm{mg}$ memiliki tingkat efikasi yang lebih baik dari pada ibuprofen $800 \mathrm{mg}(\mathrm{NNT}$ 1,6) dan ibuprofen $100 \mathrm{mg}$ (NNT 4,3) memiliki tingkat efikasi yang lebih baik dibanding ibuprofen $400 \mathrm{mg}$. Hal ini menunjukkan bahwa semakin kecil dosis ibuprofen yang digunakan, semakin baik efek analgesik yang diberikan. Sedangkan, parasetamol dosis $1000 \mathrm{mg}$ hanya memiliki nilai NNT 3,8 yang menunjukkan bahwa dosis besar parasetamol tidak memberikan efek analgesik yang lebih baik daripada ibuprofen (Ong et al., 2007). Parasetamol dan natrium diklofenak lebih sering diresepkan sebagai terapi tambahan jika pasien sesekali merasakan nyeri pasca operasi.

Tabel 4. Obat-obat yang diberikan pada pasien pasca operasi di RSUD Abdul Wahab Sjahranie periode bulan Desember-Februari tahun 2015-2016

\begin{tabular}{cccc}
\hline Nama Obat & Dosis & Frekuensi & Rute Pemberian Obat \\
\hline Asam Mefenamat & $500 \mathrm{mg}$ & $3 \times$ & Per oral \\
Ibuprofen & $400 \mathrm{mg}$ & $2 \times$ & Per oral \\
Ketorolak & $30 \mathrm{mg}$ & $2-3 \times$ & Intravena \\
& $10 \mathrm{mg}$ & $3 \times$ & Per oral \\
Natrium Metamizol & $1000 \mathrm{mg}$ & $3 \times$ & Intravena \\
Natrium Diklofenak & $50 \mathrm{mg}$ & $2 \times$ & Per Oral \\
Parasetamol & $500 \mathrm{mg}$ & $3 \times$ & Per oral \\
\hline
\end{tabular}

Tabel 4. menunjukkan pola penggunaan obat analgesik NSAID menurut dosis, frekuensi dan rute pemberiannya. Sesuai dengan literatur yang ada, frekuensi penggunaan obat analgesik yang diberikan kepada pasien pasca operasi secara keseluruhan telah sesuai. Begitu pula dengan rute pemberian obat yang digunakan, jika dikelompokkan menjadi rute tunggal oral, tunggal parenteral (intravena), dan kombinasi keduanya akan tampak seperti grafik 8 .

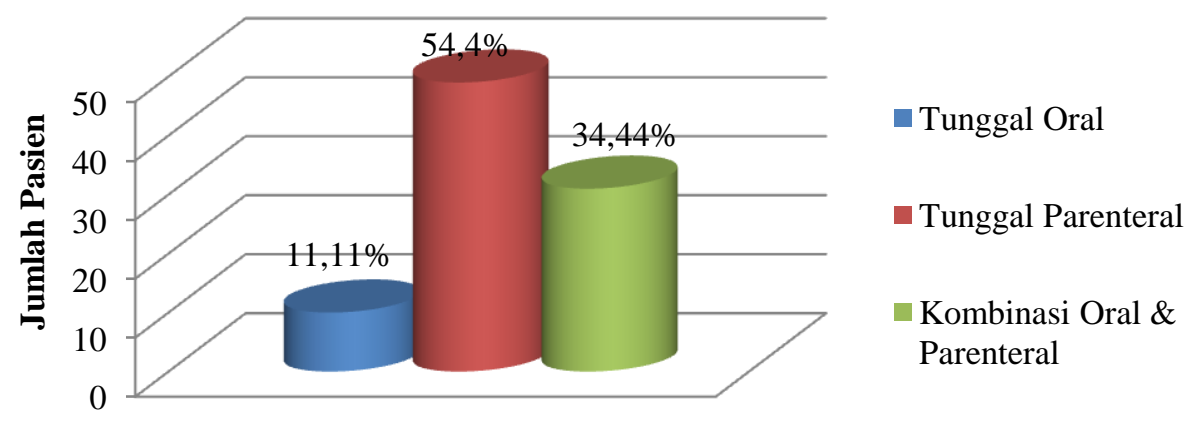

Gambar 8. Distribusi penggunaan obat analgesik berdasarkan rute pemberiannya 
Gambar 8. menunjukkan bahwa sebanyak $11,11 \%$ digunakan rute pemberian oral secara tunggal, 54,44\% rute pemberian parenteral, dan 34,44\% rute pemberian kombinasi. Dimana seperti yang telah disebutkan sebelumnya bahwa kombinasi yang dimaksudkan merupakan tahapan penggunaan obat yang berbeda selama terapi penyembuhan, bukan menggunakan dua atau lebih jenis obat secara bersamaan tetapi, secara bertahap.

Tabel 5. Kesesuaian dosis obat NSAID pada pasien pasca operasi

\begin{tabular}{llcccc}
\hline \multicolumn{1}{c}{ Nama Obat } & Golongan Obat & $\begin{array}{c}\text { Dosis } \\
\text { Lazim }\end{array}$ & $\begin{array}{c}\text { Dosis } \\
\text { Maksimal }\end{array}$ & $\begin{array}{c}\text { Dosis yang } \\
\text { Diberikan }\end{array}$ & $\begin{array}{c}\text { Kesesuaian } \\
\text { Dosis }\end{array}$ \\
\hline Asam Mefenamat & Fenamat & $500 \mathrm{mg}$ & $1000 \mathrm{mg}$ & $500 \mathrm{mg}$ & Sesuai \\
Ibuprofen & Asam propionat & $400 \mathrm{mg}$ & $3200 \mathrm{mg}$ & $400 \mathrm{mg}$ & Sesuai \\
Ketorolak & Asam karboksilat & $30 \mathrm{mg}$ & $120 \mathrm{mg}$ & $30 \mathrm{mg}$ & Sesuai \\
& pirolizin & $10-20 \mathrm{mg}$ & $40 \mathrm{mg}$ & $10 \mathrm{mg}$ & \\
Natrium Metamizol & Turunan Pirazolin & $1000 \mathrm{mg}$ & $4000 \mathrm{mg}$ & $1000 \mathrm{mg}$ & Sesuai \\
Natrium Diklofenak & Asam asetat & $50 \mathrm{mg}$ & $225 \mathrm{mg}$ & $50 \mathrm{mg}$ & Sesuai \\
Parasetamol & Para-aminofenol & $500 \mathrm{mg}$ & $4000 \mathrm{mg}$ & $500 \mathrm{mg}$ & Sesuai \\
\hline
\end{tabular}

Tabel 5. menunjukkan bahwa obat asam mefenamat $500 \mathrm{mg}$ dan parasetamol $500 \mathrm{mg}$ yang diberikan sebanyak 3 kali dalam sehari, serta ibuprofen $400 \mathrm{mg}$ dan natrium diklofenak $50 \mathrm{mg}$ yang diberikan 2 kali sehari secara oral telah sesuai dengan dosis lazim dan tidak melewati dosis maksimalnya. Begitu pula dengan obat natrium metamizol 1000 mg dan ketorolak $30 \mathrm{mg}$ yang diberikan sebanyak 2 sampai 3 kali sehari secara intravena, serta ketorolak $10 \mathrm{mg}$ yang diberikan sebanyak 3 kali sehari secara oral telah sesuai dengan dosis lazim dan tidak melewati dosis maksimalnya. Sehingga, dapat dikatakan bahwa pola penggunaan obat analgesik pada pasien pasca operasi berdasarkan dosis obatnya secara keseluruhan telah sesuai.

\section{KESIMPULAN}

Berdasarkan hasil yang telah diperoleh, dapat disimpulkan bahwa:

1. Pasien pasca operasi sebanyak $54,44 \%$ berjenis kelamin laki-laki dan $45,56 \%$ berjenis kelamin perempuan. Usia remaja sebanyak $10 \%$, dewasa $50 \%$ dan lansia $40 \%$. Tingkat pendidikan SMA sebanyak 43,3\%; SD 27,78\%; SMP 17,77\%; S1 8,89\%; Apoteker dan tidak sekolah $1,1 \%$. Jenis operasi major sebanyak $56,66 \%$ dan operasi minor $43,33 \%$.

2. Pola penggunaan obat yang diperoleh $38,88 \%$ digunakan turunan pirazolin, $14,44 \%$ turunan asam karboksilat pirolizin, 5,55\% turunan fenamat, 4,44\% turunan asam propionat, $1,11 \%$ turunan para-aminofenol, $0 \%$ turunan asam asetat dan 35,55\% penggunaan obat kombinasi. Dosis yang digunakan dari setiap terapi secara keseluruhan telah sesuai. Rute pemberian tunggal oral $11,11 \%$; tunggal parenteral $54,4 \%$; dan kombinasi keduanya 34,44\%.

\section{ACKNOWLEDGE}

Terima kasih kepada pihak DIKLIT (Bidang Pendidikan dan Penelitian), kepala ruangan rawat inap Cempaka, beserta perawat senior yang bertugas di ruang rawat inap Cempaka atas perizinannya dan kerja samanya selama peneliti melakukan peneltian disana. 


\section{DAFTAR PUSTAKA}

1. Sjamsuhidajat, R. 2010. Buku Ajar Ilmu Bedah. Edisi 3. Penerbit Buku Kedokteran EGC: Jakarta

2. Misiolek, Hanna., Maciej Cettler., Jaroslaw Woron., Jerzy Wordliczek., Jan Dobrogowski., dan Ewa Mayzner-Zawadzka. 2014. The 2014 Guidelines for PostOperative Pain Management. Anaesthesiology Intensive Therapy Volume 46, Number 4: 221

3. The Management Of Postoperative Pain. 2002. VHA/DoD Clinical Practice Guideline For The Management Of Postoperative Pain. Veteran Health Administration Departement of Defense: Washington DC

4. Ardinata, Dedi. 2007. Multidimensional Nyeri. Jurnal Keperawatan Rufaidah Sumatera Utara Volume 2, Number 2: 77-78

5. Hargreaves, K. 2006. Drugs for Pain Management in Dentistry. Australian DentalJournal Medication Supplement Volume 2, Number 50: S14

6. McClay, Helen. 2010. Pain Management in Palliative Care-Choice of Analgesia. Journal of The Malta College of Pharmacy Practice, Issue 16: 28-29

7. Depkes RI. 2009. Profil Kesehatan Indonesia. Departemen Republik Indonesia: Jakarta

8. Mahendrakrisna, Daniel., Akhada Maulana., dan Erwin Kresnoadi. 2016. Faktor yang Berhubungan dengan Rawat Inap pada Pasien Pembesaran Prostat Jinak Di Rumah Sakit Bhayangkara Mataram. Berkala Ilmiah Kedokteran Duta Wacana Volume 2 ,Nomor 2:104-106

9. Lina, N. 2008. Faktor-faktor Resiko Kejadian Batu Saluran Kemih pada Laki-laki (Studi Kasus Di RS Dr. Kariadi, RS Roemani dan RSI Sultan Agung Semarang) [Tesis]. Universitas Diponegoro: Semarang

10. Purnomo, Basuki B. 2003. Dasar-dasar Urologi, Edisi 2. Sagung Seto: Jakarta

11. Prawira M, Rizky Ananda. 2015. Evaluasi Batu Kandung Kemih Di Rumah Sakit Umum Daerah Cengkareng pada Januari-Desember 2014 [Skripsi]. Universitas Islam Negeri Syarif Hidayatullah: Jakarta

12. Riyadina, Woro., Suhardi., dan Meda Permana. 2009. Pola dan Determinan Sosiodemografi Cedera Akibat Kecelakaan Lalu Lintas di Indonesia. Majalah Kedokteran Indonesia Volume 59, Nomor 10: 466-467

13. Basavanthappa, BT. 2003. Medical-Surgical Nursing. Jaypee Brothers Medical Publishers: New Delhi

14. Committee MMS. 2011. Office-Based Surgery Guidelines. Massachusetts Medical Society

15. Jasiecka, A., T. Maslanka., J. J. Jaroszewski. 2014. Pharmacological Characteristics of Metamizole. Polish Journal of Veterinary Sciences Volume 17, Number 1: 207-214

16. Ong, C. K. S., P. Lirk, C. H. Tan, dan R. A. Seymour. 2007. An Evidence-Based Update on Nonsteroidal Anti-Inflammatory Drugs. Clinical Medicine \& Research Volume 5, Number 1: 30 